Published in the Journal of the Royal Anthropological Institute, May 2009, vol. 15: S222-S240, in a special issue, Islam, Politics, Anthropology, edited by Benjamin Soares and Filippo Osella. The definitive version is available at www.onlinelibrary.com.

\title{
ISLAM AND THE POLITICS OF ENCHANTMENT
}

\author{
GREGORY STARRETT \\ University of North Carolina at Charlotte
}

\begin{abstract}
:
The North American public sphere is suffused with claims and counterclaims about the relationship between Islam and violence. Schools and publishers have responded with training programs for teachers and curriculum units for students introducing them to the Middle East and its dominant religious tradition. Such programs are often accused by local parents and national intellectuals of pandering to Muslim sensitivities by whitewashing distasteful historical events and even proselytizing young people. Focusing on a 2002 lawsuit filed against California's Byron Union School District, by parents upset by a classroom role-playing exercise on Islam, this article argues that political fears about terrorist infiltration into U.S. society are building on powerful emotional and cultural concerns about the nature of ritual and the spiritual safety of children exposed to information about other religions. By encouraging public education as a response to political and cultural tensions, educators may in fact be heightening the public's concerns about Islam as a comprehensive threat.
\end{abstract}


The first trick-or-treater arrived at my front door promptly at 6 p.m. A boy about 7 or 8 years old, he was wearing a white turban, white slacks, a long white jacket [and] a rubber-like mask of Osama bin Laden. In one hand he carried his treat bag, in the other a toy replica of an M-16. . . I'm still outraged that any company in this country would sell a Bin Laden mask and that any parent, perhaps one of my neighbors, would purchase it for a child's costume (A 2 November 2006 letter to the Charlotte Observer).

[T] he point is that between. . .the 'thin description' of what the rehearser (parodist, winker, twitcher. . .) is doing ('rapidly contracting his right eyelids") and the 'thick description' of what he is doing ('practicing a burlesque of a friend faking a wink to deceive an innocent into thinking a conspiracy is in motion') lies the object of ethnography: a stratified hierarchy of meaningful structures in terms of which twitches, winks, fake-winks, parodies, rehearsals of parodies are produced, perceived and interpreted, and without which they would not. . . in fact exist, no matter what anyone did or didn't do with his eyelids (Geertz 1973:7).

Islam is a problem. It is held responsible for terrorism, the oppression of women, economic underdevelopment, repressive political systems, and a host of other difficulties around the world. Islam and modernity, Islam and progress, Islam and liberalism appear, in the minds of many, to be perennially at odds, perhaps irreconcilable. Over the last few years European and American governments and foundations have begun to explore increased funding for scholarly work on Muslim populations in their countries, framing such projects, at least implicitly, as the study of a social problem. How have, and how will, Muslim populations adapt, assimilate, resist, and reform themselves in non-Muslim environments? Where do they live, and what are their demographics? Are they similar to previous waves of immigrants, or qualitatively different? How can we help ensure they will not become a danger to their host societies? And at the most basic level, who counts as "Muslim" (is it a matter of belief, mosque attendance, identification, or descent) in the first place (Leonard 2003)?

Contemporary social theory often defines modernity as a set of techniques for generating particular kinds of intellectual, social, and political order, or even the phenomenon of order itself (Bauman 1990, Foucault 1977, Latour 1993, Mitchell 1988, 2002). Such arguments often revolve around the nation-state as the source and product of an unprecedented type of social and experiential ordering. Arjun Appadurai (2006) has recently extended this literature by examining the intersection of nation-state politics and globalization, looking at the fear national majority populations often feel about small minority groups. Like Bauman (1990), who traced this fear to the politically productive intellectual ambivalence created by the social category of "stranger," Appadurai writes that by spoiling the fantasy of 
categorical purity within the modern nation-state, the existence of quantifiable minorities can act as a focus for violent reaction, especially when those internal minorities are linked with global populations beyond one's borders. "Given the systemic compromise of national economic sovereignty that is built into the logic of globalization," he writes,

and given the increasing strain this puts on states to behave as trustees of the interests of a territorially defined and confined "people," minorities are the major site for displacing the anxieties of many states about their own minority or marginality (real or imagined) in a world of a few megastates, of unruly economic flows and compromised sovereignties. Minorities, in a word, are metaphors and reminders of the betrayal of the classical national project (Appadurai 2006:43).

When we think about Islam, politics, and modernity, it is insufficient, then, to restrict our attention to obvious cases of "Muslim politics" in the majority Muslim world (Eickelman and Piscatori 1996), or to the politics of "real" or even virtual Muslim populations elsewhere. As a "networked civilization" (Gilmartin 2005), a religious tradition, an act of faith, and a globalized symbol evoking emotions ranging from admiration and desire to dismissal, hostility and fear, Islam and Muslims are objects of imagination, and this imagination has implications for politics and for experiences of the modern by non-Muslims, even in places where Muslims are nearly absent.

This article examines some current controversies regarding teaching and learning about Islam in American public schools, in order to illuminate how Islam as an object of imagination can shape the experience of modernity. Focusing on the federal court case of Eklund $v$ Byron Union School District (2002), in which a California family claimed its children's public school was coercing them into Islam, I will describe how parental and community concerns about such teaching have entered the media and the judicial system, and the ways that schools, courts, and activists of various sorts have expressed their understandings of the relationship between knowledge, ritual, and personal commitment.

Appadurai's outline of a "geography of anger" posits majority fears of a "volatile morphing" in which majority and minority might switch places, and the preventive generation of "predatory identities" which seek to destroy the cultural "other" before "brute accelerated reproduction or subtler legal or political means" on the part of the minority cause such an inversion to happen $(2006: 51,85)$. Given this sense of worry, the invisible boundary between Muslim and non-Muslim status becomes an important line of demarcation, and activities normally interpreted as imagination, play, or culturally sanctioned rituals of reversal such as Halloween or schoolroom make-believe, lose their normal meaning and come to be perceived as potentially earnest expressions of self. In Geertz's idiom, the presumption of a common 
cultural framework allowing us to distinguish between twitches and winks fails. Becoming or impersonating a Muslim, notorious or not, or engaging in what seems stereotypical Muslim-like behavior even with "secular" or consciously parodic purpose, is sometimes interpreted either as crossing a dangerous cultural border or as a psychological prelude to doing so.

In the court case I analyze here, parents were concerned that children were being proselytized or being made to impersonate Muslims in public school. But as Sullivan (1994, 2005) has shown, judicial and popular understandings of ritual more broadly speak past each other. American courts generally distinguish quite finely between winks and twitches, perceiving secular purposes and effects beneath forms of action and thought which religious activists define much more specifically as sacred. Portions of the religious public, on the other hand, see pedagogical techniques and programs developed by Christian multiculturalistsmeant to teach the values of tolerance and diversity in American society--as attempts by aggressive groups of Islamic militants to highjack schools as platforms for turning the United States into an Islamic nation. The messy politics of modernity, postmodernity, and globalization are clearly not restricted to Muslim societies.

\section{Brazen Influence}

Islamist Lawfare is often predatory, filed without a serious expectation of winning, and undertaken as a means to intimidate, demoralize and bankrupt defendants (Goldstein 2008).

[The development of predatory identities includes] a successful campaign of fear, directed at numerical majorities, which convinces them that they are at risk of destruction by minorities, who know how to use the law (and the entire apparatus of liberal-democratic politics) to advance their special ends (Appadurai 2006:58).

Harvard-trained medieval historian Daniel Pipes has made his reputation combating "radical Islam" through his websites, in newspapers, and on television appearances. The intensity of his defense of "the West" derives perhaps from the fact that he is in agreement with terrorist mastermind Osama bin Laden with regard to the success such radical Islam enjoys on the world stage. At a late 2001 meeting with supporters in Qandahar, Bin Laden spoke about mass conversions to Islam in Holland and the increase in American interest in Islam resulting from the September 11th attacks: "I heard someone on Islamic radio who owns a school in America say: 'We don't have time to keep up with the demands of those who are asking about Islamic books to learn about Islam.' This event made people think (about true Islam) which benefitted 
Islam greatly." ${ }^{1}$ The idea that a cascade of nonbelievers is likely to convert voluntarily after Muslim military victories recalls contemporary Middle Eastern portrayals of the Prophet Muhammad's victory over the pagan Quraysh at the battle of Badr, after which "the fencesitters and fearful among the [pagan tribe of the] Quraysh. . . enter[ed] Islam in droves" (alDuwwa et.al. 1988:82), inspired either by feelings of awe at the divinely guided victory or by fear of the victors.

Pipes, too, sees Islam making strides in the United States. For him, this is not because of true popular interest, but because of a concerted effort by what he terms "militant Islamic groups" to coopt popular culture and academia with the goal of turning the U.S. into an Islamic nation. "More ominously yet," he wrote in right-wing activist David Horowitz's online journal FrontPageMagazine, "they wish to transform public schools at all levels into venues for spreading Islam" (Pipes 2004). "Schools and campuses are no exceptions as places where Islam can be victorious," Pipes quotes the Muslim website DawaNet.com as evidence for this fear; "We should use every opportunity to sensitize non-Muslim peers and school staff to Islam and to establish an environment in which everywhere a non-Muslim turns, he notices Islam portrayed in a positive way, is influenced by it and eventually accepts Islam" (Pipes 2004).

One of the ways such an environment is created is through the actions of local schools and school boards, state departments of education, and commercial textbook publishers. Each of these bodies, according to Pipes and his readers, is subject to pressure from "a highly successful insidious industry that is extremely well organized, well connected, legally savvy, brazenly influential, and without successful opposition" (White 2005). Examples of Islamic proselytization have multiplied in the blogosphere through the testimony of parents being picked up by various media. In Tulsa, Oklahoma, parents met in a church to oppose a workshop for public school teachers on "The Arab World and Islam" (KOTV 2004). In Middletown, Ohio, seventh-grade social studies teachers cancelled a class trip to a Cincinnati mosque over parental fears that "the students would be asked to engage in Muslim rituals while at the mosque," according to school officials (Kershaw-Staley 2004). In Scottsdale, Arizona, a seventh grade world history text was criticized for pro-Islamic bias, and parents complained that their children were forced to write biographies of Muhammad and listen to "professional Muslim speakers" who "brought prayer rugs and taught the children to pray the Muslim way. I also believe there were recitations from the Koran and possibly an Islamic 'fashion show'," (White 2005). An unnamed parent alleged that shortly after September $11^{\text {th }}$, children at the local school "were asked to get on their hands and knees and pray to Allah with the words of Islam [sic] prayer" (www.blessedcause.org). The folkloric dynamism of these charges as they zoom about the internet, surfacing here and there on conservative websites and blogs, transforms news into archetype and confused hearsay about schoolroom experiences--mixed with heavy doses of parental suspicion and anxiety--into news. One popular narrative quotes a 2002 
Kansas City Star report on Muslim third, fourth, and fifth grade children from a private Islamic school in Herndon, VA, touring local public schools to demonstrate Muslim crafts and ritual. The story quickly morphed into accusations that a Muslim diversity consultant touring public schools directed young non-Muslim students in performing Muslim prayer, seemingly confirming parental fears that Islam can only be "presented" performatively, through its instantiation in new Muslims.

Probably the most talked-about cases among parents and activists are those involving a particular $7^{\text {th }}$ grade social studies textbook, Houghton-Mifflin's Across the Centuries, and a supplementary curriculum unit called Islam: A Simulation of Islamic History and Culture, 6101100. Both were criticized by Pipes in columns in the New York Post, the Jerusalem Post, and on his blog. Across the Centuries was criticized for its allegedly apologetic tone and factual distortion, its inclusion of classroom activities meant to identify students with Muslims ("Assume you are a Muslim soldier on your way to conquer Syria in the year A.D. 635. Write three journal entries that reveal your thoughts about Islam, fighting in battle, or life in the desert,"), and for allegedly failing to distinguish between Muslim belief and historical fact. The other curriculum unit, Islam: a Simulation, was even more problematic. It outlined a three-week curriculum in which

students adopt a Muslim name ('Abdalla,' 'Karima,' etc.). It has them wear Islamic clothing: for girls this means a long sleeved dress and the head covered by a scarf. Students unwilling to wear Islamic clothes must sit mutely in the back of the class, seemingly punished for remaining Westerners. [The publisher] calls for many Islamic activities: taking off shoes, washing hands, sitting on prayer rugs, and practicing Arabic calligraphy. Students study the Koran, recite from it, design a title page for it, and write verses of it on a banner. They act out Islam's Five Pillars of Faith, including giving zakat (Islamic alms) and go on the pilgrimage to Mecca (Pipes 2002).

Islam: A Simulation was written by Terry Handy, a veteran middle school social studies teacher in Pismo Beach, California, and published in 1991 by Interaction Publishers of Carlsbad, California, which specialized in simulation exercises for schools. It was listed by the California Department of Education as a supplemental curriculum unit eligible for adoption in California schools, which, like most of the other 50 states, has adopted social studies standards requiring students to learn about Islam, its prophet, and the everyday significance of its texts and beliefs (California School Boards Association 2004). In late June 2002 The Thomas More Law Center, a conservative Catholic legal foundation, filed a lawsuit on behalf of Jonas Eklund in the U.S. District Court for the Northern District of California to prevent the Byron Union School District from using the simulation (Eklund's son Chase had taken part in the simulation during the fall of 
2001 and his younger child, Samantha, was excused at her parents' request from participation the following year). The court granted a decision in this case to the school district on 5 December 2003. The Eklunds appealed to the Ninth Circuit Court of Appeals, which agreed with the lower court's decision on 17 November 2005. On 2 October 2006 the Supreme Court declined to hear the case during its current session, but certified the American Catholic Lawyers Association to file a brief as amicus curiae ("friend of the court," a legal analysis submitted by an individual or institution who is not a direct party to a court case), as the Mountain States Legal Foundation had done in July 2006.

\section{"Try to Teach the Subject in a Non-threatening, Secular Way"}

Islam: A Simulation is contained in a 116-page packet outlining 5 phases of a three-week class simulation. It is designed so teachers can customize the unit, choosing one or more elements to use in class. On the introductory day students take a pre-test, learn about Muslim dress, customs, and history, and break into six "city groups," representing Cairo, Jerusalem, Medina, Damascus, Baghdad, and Cordova. Each city group has a caliph, a banker, a secretary, and a number of citizens who, on the subsequent days, compete in exercises labeled "Caravan Days," "Oasis Days," and "Festival Days." During Caravan Days cities compete to answer questions on Quiz cards, collect Wisdom cards and dirham scrip, and survive life events ("You failed to offer refreshments to your guest. Lose 1 dirham." "While on your last caravan, your herd increased by three camels, five goats, and 12 sheep. Gain 15 dirhams"). During Oasis Days, students learn more about Islamic beliefs, practices, and history, doing simulated activities and role-playing historical caliphs. The simulation builds to Festival Days, during which each city presents a project (art, food, music, or a more traditional presentation about Islam), and ends with the Islamic Bowl, a contest in which each qualifying city chooses contestants for a game testing Islamic knowledge.

According to court records, Chase Eklund's teacher had her students choose Arabic names, and then focused on the "Oasis Days" elements of the simulation, including having the city groups engage in activities "analogous to" the five pillars of Islam. The children heard prayers and portions of the Qur'an read aloud in class, recited a line from prayer (e.g. the basmallah, "In the name of God, the Merciful, the Compassionate") on their way out of class, and made group banners featuring the basmallah (in Arabic script or in English translation) as analogues to the shahada, the Muslim declaration of faith, and salat, prayer. Students gave up eating candy or watching television for a day, and did community service projects as analogues to the Ramadan fast and the payment of zakat, or alms. As an analog to the pilgrimage, 
competed in a board game called "Race to Makkah," moving markers around a game board while answering questions about Islam. The simulation's general instructions to classroom teachers reminds them of the sensitivities potentially arising from the exercise, and advise them to teach in a "nonthreatening, secular way," framing the simulation as a historical and cultural activity rather than a ritual or religious one.

\section{Ritual Arbitration}

Students should comprehend the religious ideas that have helped to shape Western and Eastern cultures and civilizations; they should become aware of the influence of religion on lifestyles. . and on the development of ideas. The teacher should assist students to understand religious views that can be quite unfamiliar in the United States. Care should be taken, however, to avoid emphasizing unusual religions or religious practices so that respect for religion will not be undermined (California Department of Education 1994, quoted in CSBA 2002:21).

The case of Eklund v. Byron Union School District hinges on the special nature of roleplaying exercises and whether they are similar enough to religious ritual to trigger a valid claim that the public school is violating the Constitution. The United States Constitution contains two directives regarding religious practice, the Establishment Clause ("Congress shall make no law respecting an establishment of religion"), and the Free Exercise clause ("or prohibiting the free exercise thereof"). Recent Supreme Court rulings regarding violations of these constitutional guarantees have identified five principles or tests by which state action may be found to have violated the Constitution. These are the three part "Lemon test," set down by Chief Justice Warren Burger in the case of Lemon v. Kurtzman in 1971, and refinements of the third element of the Lemon test in Lynch v. Donnelly (1984) and Lee v. Weisman (1992). ${ }^{2}$

The Lemon test specifies that in order to meet Constitutional requirements, government action must 1 ) have a secular purpose; 2 ) not have the primary effect of advancing or inhibiting religion; and 3) not foster excessive government entanglement with religion. In the 1984 Lynch case, Sandra Day O'Connor posed the "entanglement" principle as a matter of "government endorsement or disapproval of religion," so that a state agency would be in violation of the Constitution if their action "sends a message to nonadherents that they are outsiders, not full members of the political community, and an accompanying message to adherents that they are insiders, favored members of the political community" (Lynch v. Donnelly 1984:16). The Supreme Court's ruling in the Lee case developed a supplementary test to O'Connor's endorsement rule, that the government "may not coerce anyone to support or participate in religion or its exercise" (Lee v. Weisman 1992:6). 
The Eklund plaintiffs argued in District court that although the state of California is justified in teaching students about the basics of Islamic religion and culture, role-playing games are an improper way of doing so, because the Islam simulation asked students "to role-play or perform activities that were roughly analogous to each pillar [of Islam]" (Eklund v. Byron 2003:8), and that these activities "taken as a whole, constitute the practice of Islam" (Eklund v. Byron 2003:11). Seventh graders, the plaintiffs argued, "could reasonably have believed they were practicing the Islam [sic] religion, even if in fact they were not, and the students could also have believed that their grade in the class would be based on their willingness to believe the tenets of Islam" (Eklund v. Byron 2003:14). In addition, they claimed that certain elements of the Islam simulation included the presentation of Islamic beliefs as matters of historical fact, and that the teacher of Chase's class, (non-Muslim) Brooke Carlin, instructed students to write essays supportive of Islam.

District Court judge Phyllis Hamilton ruled, on the contrary, that neither the facts of the case nor the precedents and principles of law developed over the last thirty years lent support to the plaintiffs' claims. Carlin had not referred to students by their Arabic names, although the students sometimes used the names in a joking manner outside class. When giving students their instructions, she had "specifically emphasized that the module was merely a role-playing game and that the students would not actually become Muslims through their participation in the module" (Eklund v. Byron 2003:3), a point confirmed by students in other sections of the class and not denied by Chase Eklund. When distributing wisdom and quiz cards bearing statements like "The Holy Qur'an is God's word as revealed to the Prophet Muhammad," she had explained that these were Muslim beliefs rather than historical fact. And Chase himself had done previous role-playing simulations, including a mock Senate in U.S. history and one on medieval Europe in which he dressed as a priest (he had declined to dress in Muslim garb for the Islam simulation). He remembered dressing as a priest, but did not associate it with religion: "That doesn't have anything really to do with God or anything or anybody that you look up to" (Eklund v. Byron 2003:6). He did not believe he had become a senator or a priest through participation in these exercises.

Hamilton's legal analysis of the possible Establishment clause violation centered largely on the extent to which the role-playing activities during the Oasis Days might have been religious, given that "students were asked to role-play or perform activities that were roughly analogous to each pillar [of Islam]" (Eklund v. Byron 2003:10). Whether these activities are impermissible depends both on whether students felt compelled to participate, and on "an objective review of whether the students were actually practicing a religion" (Eklund v. Byron 2003:11). The defendants argued, the plaintiffs' experts admitted, and the judge agreed that the students had not performed the actual five pillars of faith in their class, and that while their activities may have been analogies or "approximations" of Islamic behavior, they were not 
"actually the Islamic religious rites. . . . [and that] Role-playing activities which are not in actuality the practice of a religion do not violate the Establishment Clause" (Eklund v. Byron 2003:12-13).

This finding applies even when simulations resemble religious rituals far more closely than did those in Islam: a Simulation. As the California School Boards Association argued in an brief to the $9^{\text {th }}$ Circuit Court of Appeals regarding the appeal of Eklund, the court had previously found in the 1992 case of Brown v. Woodland (see below) that

Some student participatory activity involving school-sponsored ritual may be permissible even under [the Establishment Clause] where the activity is used for secular pedagogical purposes. For example, having children act out a ceremonial American Indian dance for the purpose of exploring and learning about American Indian culture may be permissible even if the dance was religious ritual. Similarly, a reenactment of the Last Supper or a Passover dinner might be permissible if presented for historical or cultural purposes (CSBA 2002:11).

What mattered were the intent element of the Lemon test, the context in which such rituals were performed, and the attitude of students. In both the Brown and Eklund cases, the line was drawn between "genuine" ritual, on the one hand, and activities that teach "in an engaging manner," but "did not occur in a sacred or worshipful manner" (CSBA 2002:11), and were without "devotional or religious intent," or with a "subjective lack of spiritual intent" (Eklund v Byron 2003:13), on the other. Since "the students subjectively understood the distinction between the simulation and their actual religious faith," (Eklund v Byron 2003:15), there was no Constitutional violation.

\section{Worshipful Attitudes}

But learn, at least, your inability to believe, since reason brings you to it, and yet you cannot believe; try then to convince yourself, not by the augmentation of proofs of the existence of God, but by the diminution of your own passions. . . . [L]earn from those who have been bound like yourself. . .these know the road that you wish to follow. . . .Follow their course, then, from its beginning; it consisted in doing all things as if they believed in them, in using holy water, in having masses said, etc. Naturally this will make 
you believe and stupefy you at the same time (from Blaise Pascal, The Wager, emphasis added).

The issue of worshipful attitude in the Eklund decisions specifies the courts' understanding of ritual. True ritual practice, as opposed to simulation, is practice engaged in with a particular set of mental dispositions (focus, sobriety) and emotional states (humility, love, fear). In "real" Islamic prayer, of course, as in other traditions (Garrett 1997), intention is a vital element of making prayer valid and effective as a means of communicating with God. This approach to ritual assumes that proper intention and worshipful attitude not only accompany but precede ritual performance. One enters the performance of ritual once a decision to do so has been made, and the mental state of the worshiper has been adjusted or prepared to provide the internal context for a performance which is then serious or sincere. There are other ways to think about these connections, though. Durkheim's discussion of rituals as activities "which take rise in the midst of. . .assembled groups and which are destined to excite, maintain, or recreate the mental states in these groups" (Durkheim 1965:22) is the most obvious theoretical sanction for Pascal's practical observation that ritual can nurture worshipful mental states rather than result from them. As Saba Mahmood (2004) and Charles Hirschkind (2006) have shown, there are substantial movements in Egypt and elsewhere which conceptualize ritual practice as means for cultivating proper attitudes and mental and emotional states.

This understanding of the connection between ritual and belief is of long standing. In the sixteenth and seventeenth centuries nonconformist activists and Anglican clergy in England debated the twin issues of public liturgical activity and the ethical status of theater. Both parties argued, for different purposes, that the mimicry or enactment of roles which did not match the actor's internal state could effectively transform that state. Critics of the theater argued that acting was dangerous to performers and audiences because such temporary hypocrisy could collapse the gap between an enactment on stage and the performer's own personality, transforming the performer's inner state by bringing it into concert with what it was mimicking. Churchmen used the same theory of influence to argue that private devotion and prayer were insufficient for personal transformation. True piety required not only private prayer but public enactment of standard liturgical forms so that the inner state of worshipers would be brought into concert with the rest of the congregation (Targoff 1997).

The United States Supreme Court's jurisprudence on the religion clauses of the First Amendment has not followed this logic. For the first several decades of its dealing with religion cases, beginning with Reynolds v. United States in 1879 (a case restricting Mormon polygamy), the Court solved the problem of free exercise simply by distinguishing between religious belief, which was constitutionally protected, and religious action, which could be regulated by statute. 
The Court implicitly endorsed a Protestant valuation of belief over ritual (Sullivan 1994, 2005; see Smith 1956 [1889]:16) in which the former was both the necessary core and sufficient expression of religion. While beliefs could not necessarily justify otherwise illegal activity, particular kinds of belief were necessary to qualify actions as religious. The Reynolds case was cited, for example, by a Texas court ruling in 1903, that local restrictions on alcohol consumption could be enforced against Jews but not Roman Catholics. In the view of the court, in Jewish tradition alcohol was not a sacrament. Even though its use was required at some points in the ritual calendar, the court wrote, "Such use of wine has no symbolical or mystical meaning, and is in no sense for sacramental purposes, but is used on such occasions as a beverage" (quoted in Cookson 2001:11). Action sanctioned by tradition but not derived from an explicit theological imperative did not count as ritual, because, implicit in the court's logic, legitimate ritual is an expression of preexisting dogma.

The concerns expressed by some parents and pundits with regard to Islam: a Simulation play on a very different understanding of the connection between ritual and belief. In a broader cultural context, parental fears of Islamic ritual are not merely the result of a tense world situation and a perceived clash of civilizations symbolized most powerfully by the terrorist attacks of September $11^{\text {th }}, 2001 .^{3}$ Those concerns emerge also from two other assumptions about religious life. Many parents do not merely assume, with the courts, that beliefs generate ritual action, and that ritual action is meaningful only as an expression of belief. Instead, they perceive both speech and ritual as activities with transformative psychological or spiritual effects. Ritual is not merely the enactment of belief, but can be belief's gateway.

Related to this implicit theoretical stance is a widespread substantive set of popular American beliefs about intercourse with demonic forces, and specifically the belief that Islam has a demonic origin. A recent survey by the Council for American Islamic Relations reports that as many as $10 \%$ of Americans believe Muslims are pagans who worship a moon god or goddess, ${ }^{4}$ a belief energetically disseminated by some Christian activists. In February 2007, for example, a social studies teacher at Enloe High School in Raleigh, North Carolina, invited a speaker from Kamil International Ministries to his $9^{\text {th }}$ grade social studies class. Kamil Solomon, an Egyptian-born Christian evangelist, distributed pamphlets to students (including at least one Muslim girl) that called the prophet Muhammad "demon possessed" and "inspired by Satan," and said that his "militant commands and pagan beliefs are contained in the Koran," which is "the book of Islam that Muhammad claimed was revealed to him by Allah, the moon god of Arabs" (Shimron 2007a, 2007b, 2007c; for the text of the handouts, see http://kimo4jesus.org). In Rockland County, New York, in April 2007 a Christian prison chaplain was disciplined for distributing similar literature-a Chick Publications religious tract calling Allah an idol--to inmates. The tracts led to arguments and "to inmates labeling Muslim detainees devil 
worshipers" (Clarke 2007). Far from being a fellow, if troubling, monotheism, Islam is portrayed as a heathen belief with Satanic roots.

Folklorist Bill Ellis $(2000,2004)$ and others have shown that as rumor panics about witchcraft and Satanic ritual abuse spread across the United States during the 1970s and 1980s through churches and professional networks of police, therapists, child welfare specialists, and the mass media, one pervasive theme was the ease with which children and teenagers could be unwittingly drawn into demonic activity. Occult books, not to mention idle experimentation with seemingly harmless witchcraft or New Age rituals such as the ubiquitous Ouija Board, ${ }^{5}$ could easily entrap young people and render them helpless to resist Satanism. Even some law enforcement officers charged with investigating occult rumors came to believe that the "intense study of resource books and materials by occult sources or practitioners is hazardous. . .The unknown realm of the occult beckons with many lures. Study and/or experimentation are to be avoided" (quoted in Ellis 2004:48-49). Other evangelical Christian groups talk about powerful religious language being "ingested" by worshipers, or even "impregnating" them (Coleman 2000:118, 171), both metaphors for processes that are initiated by acts of will, but which then proceed outside the control of volition to assimilate into or transform the individual's substance. This necessitates that the believer take great care of the sorts of language, music, and imagery to which he exposes himself, lest he open himself to spiritual corruption.

The connection between the Eklund case and concerns about the occult was highlighted when presiding judge Phyllis Hamilton cited a similar case from a decade earlier. The case of Brown v Woodland (1992) centered on parental objections to a children's literature series called Impressions, used in California elementary schools. Parents Katherine and Douglas Brown argued that the Impressions series contained more than three dozen (out of several thousand) selections from literature describing witchcraft and magical practices and therefore had the effect of "endors[ing] and sponsor[ing] the religions of Witchcraft and or Neo-Paganism in violation of federal and state constitutional separation of church and state principles" (Brown v Woodland:1). The California School Boards Association, in its amicus brief for the Eklund appeal, cited Brown $v$ Woodland in addition to another case regarding the Impressions series, Fleischfresser v Directors of School District 200 (1994), from the US Seventh Circuit Court of Appeals in Illinois.

The Brown and Fleischfresser cases both involved the issue of role-play, in this case, lesson plans encouraging children "to prepare and cast chants and spells and to practice being witches" (plaintiffs quoted in Fleischfresser 1994:3) as part of their engagement with stories about the supernatural. The plaintiffs in Brown argued that such activities "convert neutral reading into sponsorship and promotion of the practice and belief systems of Witchcraft and Neo-Paganism" (Brown v Woodland 1992:11). While both courts agreed that witchcraft and 
neo-paganism could be considered religious practices, they rejected the plaintiffs' arguments in part because the intent of the exercises was secular (a point to which we will return), the effect of the exercises would have been negligible in the context of the entire curriculum, even from the standpoint of an impressionable child, and because elements of witchcraft and neopaganism are so much part of American popular culture that their use in a literature curriculum did not represent excessive state entanglement with religion.

As Benjamin Soares (2005) has shown in the case of Mali, and John Bowen (1993) in Indonesia, it is precisely the widespread nature of such pagan practices and ideas that prove most troublesome to pious activists living in states which are officially "secular" but which cannot avoid involvement in religious life. In the context of the broad availability of communications media, such activists can use their skills and energy to express the concerns of ordinary people who face challenges to their beliefs and values in the public sphere (Soares 2005). In the American context, the use of the Impressions literature series was upheld despite ritual elements that the court admitted could be part of some religious tradition somewhere, perhaps even the identifiably real but minority religions of witchcraft or neo-paganism. But merely because governmental activity "happens to coincide or harmonize with the tenets of some or all religions," (a finding from Harris v. McRae in 1980, quoted in Brown v Woodland:11), this does not automatically result in an Establishment Clause violation. The courts ruled that the secular intent of Impressions rested not only on its reflection of the cultural diversity of North American society (Brown $v$ Woodland:16) and its teaching of the value of tolerance (Fleischfresser $v$ Directors:8) by encompassing many cultural traditions, but especially through its uses of enchantment.

According to the court, this enchantment is not the literal phenomenon of Christian parental fears--an entrapment into occultism and damnation--but a mind-broadening door into modern consciousness through an intense but temporary engagement that results in the development of creativity, imagination and psychological flexibility.

[The literature series] invokes mystery and imagination associated with folklore to promote learning. . . . Religions also invoke mystery and imagination for their own special purposes. However, the convergence of religious themes with the outcroppings of mystery and imagination contained in Impressions does not afford a constitutional basis for circumscribing the teaching tools available to educators (Brown v Woodland:17).

Judges on the Seventh Circuit Court of Appeals in Illinois elaborated on this point: 
[T]his 'religion' that is allegedly being established seems for all the world like a collection of exercises in "make-believe" designed to develop and encourage the use of imagination and reading skills in children... The purpose of the series, stated by the publisher. . . is that the inclusion of a variety of stories serves to stimulate a child's senses, imagination, intellect, and emotions; according to the publisher, this is the best way to build reading skills. This reading series includes works of C.S. Lewis, A.A. Milne, Dr. Seuss, Ray Bradbury, L. Frank Baum, Maurice Sendak and other noted authors of fiction. Further, these works, and so many others that are part of any elementary classroom experience have one important characteristic in common; they all involve fantasy and make-believe to a significant degree. The parents would have us believe that the inclusion of these works in an elementary school curriculum represents the impermissible establishment of pagan religion. We do not agree. After all, what would become of elementary education. . . without works such as these and scores. . .of others that serve to expand the minds of young children and develop their sense of creativity? With that off our chest, we can now properly dispose of the parents' claim within the structure of the Lemon test (Fleischfresser v Directors:6).

Fantasy and make-believe, according to this extra-legal aside, are "skills. . fundamental to children of this age, and it is critical that the [schools] select the best tools available to them to teach these skills" (Fleischfresser v Directors:8). It is possible to read these cases as translations into legal idioms of different interpretations of the spiritual and psychological power of ritual, rather than merely as adjudications of the abstract principal of state sponsorship. The court's evaluation differs from that of the parents in that it sees enchantment as a path to the development of a flexible consciousness, while parents see it as linked, always, with a specific content that both narrows and misleads.

\section{Magical Thinking and Modernity}

That children in the United States are expected to learn the skills of fantasy and make-believe as a matter of course, while the children of Manus (Mead 1932) and other "traditional" cultures might not, is one of the key features of the idea of modernity. If the category of "stranger" disrupts the ordering power of the nation-state's fundamental opposition between friend and enemy (Bauman 1990), it is the undecidability of the stranger's intentions, rather than lack of knowledge about his beliefs, that proves most perplexing. "The commitment the stranger declares cannot be trusted" (Bauman 1990:150) precisely because one's imagination has been primed to appreciate his difference. Half a century ago, sociologist Daniel Lerner, in his classic articulation of modernization theory, The Passing of Traditional Society, wrote that 
The model of behavior developed by modern society is characterized by empathy, a high capacity for rearranging the self-system on short notice. . .[T]he interdependent sectors of modern society require widespread participation. This in turn requires an expansive and adaptive self-system, ready to incorporate new roles and to identify personal values with public issues. This is why modernization of any society has involved the great characterological transformation we call psychic mobility (Lerner 1958:51).

Empathy, the ability to imagine oneself in another's place, is a central psychological feature in this reading of modernity, as it allows the modern personality to imagine and accomplish selfdirected change and to predict, appreciate, and use the perceptions, understandings, and goals of others. Classroom simulations try to develop this sort of understanding in a more or less literal way through the temporary, restricted and shallow reenactment of other lifeways. The goal, for Lerner, was a psychic flexibility that would allow personal change and transformation within the context of social and economic development. For contemporary educators, the goal is both socioeconomic and moral: to encourage an understanding of cultural diversity and promote tolerance in the context of an irreducibly multicultural society and encompassing "global village."

But as literature scholar Stephen Greenblatt notes in an argument about the way this mobile personality served the European colonial project that began in the sixteenth century, "What is essential" in this Western sense of empathy

is the Europeans' ability again and again to insinuate themselves into the preexisting political, religious, even psychic structures of the natives and to turn those structures to their advantage. ... There are periods and cultures in which the ability to insert oneself into the consciousness of another is of relatively slight importance,. . .others in which it is a major preoccupation, the object of cultivation and fear. Professor Lerner is right to insist that this ability is a characteristically (though not exclusively) Western mode. . .he misleads only in insisting. . . that it is an act of imaginative generosity, a sympathetic appreciation of the situation of the other fellow. ... .[W]e must understand that he is speaking of the exercise of. . . power, power that is creative as well as destructive, but that is scarcely ever wholly disinterested or benign (Greenblatt 1980:227-228).

Such power depends on "the ability and willingness to play a role, to transform oneself, if only for a brief period and with mental reservations, into another. This necessitates the acceptance of disguise, the ability to effect a divorce. . . between the tongue and the heart. Such role- 
playing in turn depends upon the transformation of another's reality into a manipulable fiction" (Greenblatt 1980:228), the use of make-believe "as foundation of an all-too-seriously serious reality," which Taussig (1993:255) sees as a fundamental element of human experience central to the process of creating cultural "others." Recent proposals by U.S. government agencies, consultants, and private organizations to respond to the threat of globalized radical Islam through a public diplomacy offensive, seeking to encourage particular forms of Islamic thought and practice (Kaplan 2005, Mahmood 2006, Benard 2004, Rabasa and Benard 2007), derive in part from a confidence that we can rearrange the theology and devotional practices of others by imagining and supporting alternative Islams, often Islams developed by thinkers whose own psychic flexibility derives from modern forms of education and match our own or that of our modernist ancestors (Starrett 2008).

In Eklund v. Byron, the "other's" reality is Islam, and its manipulability as fiction is simultaneously the goal of one non-Muslim party and the fear of the other. From the perspective of contemporary evangelical culture, Islam as a demonic and proselytizing reality cannot be manipulated, even in fictional form, without spiritual danger. Anyone encouraging such practice in the classroom is a de facto ally of Islamist radicals, a popular reaction that led one schoolteacher involved in a controversy over teaching about Islam to remark ruefully that in the public consciousness he had been suddenly transformed from "a Methodist boy from the deserts of California. . . into a pro-Muslim fundamentalist multiculturalist activist" (personal communication, 28 February 2007).

Added to this cultural concern is the more strictly legal question of the boundaries and uses of ritual in secular contexts. Is an analog to ritual action ritual itself? Is it part of a devotional and therefore illegitimate ritual whose aim is "learning Islam," or part of a secular and therefore legitimate schoolroom ritual whose aim is "learning about Islam"? And does it make a difference in our multicultural society precisely whom the targets of these exercises are? Can a Muslim student be expected to simulate "her own culture" in the context of schoolroom lessons? The Council on Islamic Education, one of the allegedly "militant Islamic groups" Daniel Pipes has accused of pressuring textbook publishers and school districts to use their power to indoctrinate children in Islam, has itself criticized the use of role-playing exercises in public schools (see www.cie.org). The CIE advances two main reasons for cautioning against such exercises, both drawn from guidelines developed by a nonprofit organization called The First Amendment Center and endorsed by almost twenty American religious and educational groups (Haynes 1999). First, according to CIE,

Simulating acts of worship or mimicking the language of beliefs and personal identity can trivialize deeply held ideas and spiritual experiences. It is not necessary to inhabit another's religious beliefs in order to learn about differing belief patterns.... Second, 
such role-playing activities simulate conforming to a particular religion by following some or all of its practices. As such, these activities violate. . the principles that study of religion must be academic and not devotional, that teaching about religion must not seek to conform students to a religion, and that the teaching neither denigrates or promotes any religions or religion per se. . . . To see how inappropriate such role-playing activities are, one need only ponder the possibility that a student who practices the religion in question is present in the class. How could they perform the "simulation"? (www.cie.org)

Such simulations are deployed more often than we might think, though, as Muslim Student Associations sponsor Ramadan "Fast-a-Thons" on college campuses, raising consciousness and resources by having non-Muslim students sign up to fast for a day during Ramadan in return for community or corporate donations of food or money to local charities (600 students signed up for the 2006 Fast-a-Thon at Indiana University in Bloomington, and 30 at Texas State University in San Marcos). On a number of college and even high school campuses, non-Muslim women-with the encouragement of local Muslim organizations and individuals as well as their non-Muslim social studies teachers-have donned hijab, or modest dress, for short periods of time to investigate the everyday discrimination, anxiety and hostility veiled women attract in the United States. The objectified form of exotic ritual has multiple uses.

\section{Conclusions}

Social conflict is not something that happens when, out of weakness, indefiniteness, obsolescence, or neglect, cultural forms cease to operate, but rather something which happens when, like burlesqued winks, such forms are pressed by unusual situations or unusual intentions to operate in unusual ways (Geertz 1973:28).

The Center for Islamic Education's concerns about burlesqued winks at Islam are matched by the concerns of some Christian activists about those same winks as rehearsal. At least three theories of ritual action are at stake in Eklund and related cases. In the first, ritual is a coercive tool to distance children from their parents' religious heritage. As noted above, for some Protestants this theory is informed by a theological conception of demon-inspired writing and ritual which draws people into intercourse with dark spirits and entraps them. The Center for Islamic Education and others like the lawyers of the Thomas More Law Center and the American Catholic Lawyer's Association may be informed by a less suspicious but more widespread view of ritual as a central element of specific religious traditions that helps bind the 
congregant to the past, the present, and the future community of worship. Engaging in the rituals of a tradition to which one does not acknowledge membership or commitment is evidence of inauthenticity and must be the result of misunderstanding, coercion, hypocrisy, or evil intent.

The third theory of ritual is that of teachers and the courts, for whom some limited types of coercion-and even the performance of rituals acknowledged as sacred to particular traditions, as long at they are approached with "secular" intent--are legitimate for the sake of learning, a particular kind of psychological transformation which is assumed not to affect the student's relationship to family social identities or spiritual loyalties. Ritual and ritual-like action are legally troublesome only if approached with a particular set of cognitive or emotional orientations. But much of the contemporary anthropology of ritual takes a different view. Humphrey and Laidlaw (1994) have argued, like Robertson Smith (1956[1889]) and Rappaport (1983), that action belonging to the abstract category of "ritual" is independent of the intentions or understandings of its participants, and that engagement in ritualized action is a kind of "performative thinking" that demonstrates a particular kind of commitment to, or even the creation of, entities outside the self (Houseman 2005). To expand on this analysis, it is worth pointing out that these entities might be anything: an idea, a person, a deity, an institution, a kinship group, a tradition, a social relationship.

From this perspective, the difference between ritual and the "simulation" of ritual becomes clearer. If ritual is a culturally meaningful act in Geertz's sense (even if not defined by the mental state or intention of any particular actor), then its simulation is not a meaningless act, but rather an act which is meaningful relative to a different set of entities, entities potentially unspecified in the ritual's own manifest content. In this case, the enactment is relative to the values of tolerance, cosmopolitanism, and diversity, or to the very modernist attitude that Lerner attributed to developed societies. In a more specific sense, these are rituals not of Islam, but rituals relative to Islam as a member of the category of "world religions" rather than merely the national religion of the Arabs (Masuzawa 2005) or one of the "unusual religions or religious practices" that the California Department of Education feared might undermine respect for religion as such (CSBA 2002:21). Schoolroom rituals are also meaningful relative to traditions of pedagogy charged with developing imagination and creativity "for their own sake" as taken-for-granted elements of psychological well-being. And finally, they are practical responses to the difficulty of teaching history to middle grades students, whose teachers assume that the participatory nature of dramatic or ritual enactments holds their attention long enough to slide "secular" information into their brains. Like other daily rituals, they help define the relationship between student and teacher.

In thinking through "the dark side of globalization" Appadurai noted that one of the many uncertainties common in the modern world "is about whether a particular person really is 
what he or she claims or appears to be or has historically been.... [L]ocal and regional forms of cultural fundamentalism may be seen as part of an emerging repertoire of efforts to produce previously unrequired levels of certainty about social identity [and] values" (2006:6-7; see also Bauman 1990, 1991). Absent or much attenuated in such fundamentalisms-whether religious or secular--is the ability to contextualize public representations of identity in complex or nuanced ways. Absent also is an appreciation that the depth of one's discomfort with the identities of Others might be more severe the closer they are to one's own (Harrison 2002). While Appadurai's analytical framework attaches the adjective "predatory" to majority populations seeking to halt the growth and influence of minorities, anti-Muslim activists in the United States attach it to the phenomenon of Muslim civil and legal engagement (Goldstein 2008).

For Geertz, the chief difficulty in understanding people of other cultures is "a lack of familiarity with the imaginative universes within which their acts are signs" (1973:13). Like Lerner, he thinks of the modern consciousness as one in which a flexible generosity of spirit prompts us to seek a morally engaged conversation with others aimed at "the enlargement of the universe of human discourse" (1973:14). Greenblatt and Taussig might reply that the issue of cultural gulfs is partly a matter of the different degrees of power people have to choose which imaginative universe is to be the framework in which given actions are to be interpreted. ${ }^{6}$ Unlike non-Muslim projects to reform Islam, schoolroom simulations and Muslim "ritual outreach" activities like Fast-A-Thons evoke imaginative universes of religious ritual, but do so with properly court-sanctioned secular intent, seeking neither to represent nor to create "sacred and worshipful" orientations. They may even act as buffers between the understandings and interests of Muslims and non-Muslims, preventing either from engaging too directly or explicitly with assumptions and experiences underpinning the imaginative universes of the other.

Ritual simulation, being something that anyone might do, interferes with the certainty about identity Appadurai and Bauman identify as one of the urgent desires of a modern, mobile world. For some communities concerned about the politics of Islam, the experience of modernity is one in which it is possible to believe that their governing agencies and educational institutions are collaborating with Muslim minorities to convert children to Islam in the interest of "secularism," "tolerance," or "multiculturalism." As the twenty-first century proceeds, we can hope that these experiences and these perceptions of an insidious politics of enchantment do not result in the development of further predatory identities. 


\section{Legal Cases Cited}

All cases can be consulted through the Lexis/Nexis database.

Brown v. Woodland Joint Unified School District. 1994. $9^{\text {th }}$ Circuit Court of Appeals.

Eklund v. Byron Union School District. 2003. United States District Court for the Northern District of California.

Eklund v. Byron Union School District. 2005. 9th Circuit Court of Appeals.

Fleischfresser et. al. v. Directors of School District 200. 1994. $7^{\text {th }}$ Circuit Court of Appeals.

Lee v. Weisman. 1992. Supreme Court of the United States.

Lemon et. al. v. Kurtzman, et. al. 1973. Supreme Court of the United States.

Lynch v. Donnelly et. al. 1984. Supreme Court of the United States.

\section{Bibliography}

Appadurai, A. 2006. Fear of Small Numbers: An Essay on the Geography of Anger. Durham, NC: Duke University Press.

Bauman, Z. 1990. "Modernity and Ambivalence." In Mike Featherstone, ed. Global Culture:

Nationalism, Globalization and Modernity. London: Sage Publications, pp. 143-170.

Benard, C. 2004. Civil Democratic Islam: Partners, Resources, and Strategies. Rand Corporation.

Bowen, J. 1993. Muslims Through Discourse: Religion and Ritual in Gayo Society. Princeton, NJ: Princeton University Press.

California School Boards Association. 2004. Amici Curiae Brief to the US Court of Appeals, $9^{\text {th }}$ Circuit, in the case of Eklund v. Byron Union School District. 
Clarke, S. 2007. "Rockland jail suspends chaplain over anti-Islam booklets," first published and accessed 13 April at http://www.nynews.com.

Coleman, S. 2000. The Globalisation of Charismatic Christianity: Spreading the Gospel of Prosperity. Cambridge: Cambridge University Press.

Cookson, C. 2001. Regulating Religion: The Courts and the Free Exercise Clause. New York: Oxford University Press.

Durkheim, E. 1965. The Elementary Forms of the Religious Life. Trans. Joseph Ward Swain. New York: Free Press.

al-Duwwa, M, et. al. 1988. Al-Tarbiya al-Islamiyya. Cairo: al-Jihaz al-Markazi lil-Kutub alJami iyya wa al-Madrasiyya wa al-Wasa'il al-Ta limiyya.

Eickelman, D. F., and J. Piscatori. 1996. Muslim Politics. Princeton, NJ: Princeton University Press.

Ellis, B. 2000. Raising the Devil: Satanism, New Religions, and the Media. Lexington: The University Press of Kentucky.

2004. Lucifer Ascending: The Occult in Folklore and Popular Culture. Lexington:

University Press of Kentucky.

Foucault, M. 1977. Discipline and Punish. Trans. Alan Sheridan. New York: Pantheon.

Garrett, C. 1993. "The Rhetoric of Supplication: Prayer Theory in Seventeenth-Century

England." Renaissance Quarterly 46, 328-357.

Geertz, C. 1973. "Thick Description: Toward an Interpretive Theory of Culture," in his The Interpretation of Cultures. NY: Basic Books.

Gilmartin, D. 2005. “A Networked Civilization?" In miriam cooke and Bruce B. Lawrence, eds., Muslim Networks from Hajj to Hip Hop. Chapel Hill: University of North Carolina Press, pp. 5168.

Goldstein, B. 2008. "Welcome to 'Lawfare'-A New Type of Jihad," http://www.familysecuritymatters.org/terrorism.php?id=1387239, accessed 14 April 2008. 
Greenblatt, S. 1980. Renaissance Self-Fashioning. Chicago: University of Chicago Press.

Handelman, D., and G. Lindquist. 2005. Ritual in its Own Right. New York: Berghahn Books.

Handy, T. 1991. Islam: A Simulation of Islamic History and Culture, 610-1100. Carlsbad, CA: Interaction Publishers.

Harrison, S. 2002. "The Politics of Resemblance: Ethnicity, Trademarks, Headhunting." Journal of the Royal Anthropological Institute 8, 211-232.

Haynes, C. 1999. A Teacher's Guide to Religion in the Public Schools. Nashville, TN: First Amendment Center.

Hirschkind, C. 2006. The Ethical Soundscape: Cassette Sermons and Islamic Counterpublics. New York: Columbia University Press.

Houseman, M. 2005. "The Red and the Black: A Practical Experiment for Thinking About Ritual," pp. 75-97 in Handelman and Lindquist 2005.

Humphrey, C., and J. Laidlaw. 1994. The Archetypal Actions of Ritual: A Theory of Ritual Illustrated by the Jain Rite of Worship. Oxford: Clarendon Press.

Kaplan, D. E. 2005. "Hearts, Minds, and Dollars." U.S. News and World Report. 23 April.

Kershaw-Staley, T. 2004. "Mosque Trip Yanked," Middletown Journal.com, 26 February.

KOTV. 2004. "Tulsa Parents Express Concern over Teacher Workshop on Islam," http://www.kotv.com

Latour, B. 1993. We Have Never Been Modern. Trans. Catherine Porter. Cambridge, MA: Harvard University Press.

Leonard, K. 2003. Muslims in the United States: The State of Research. New York: Russell Sage Foundation. 
Lerner, D. 1958. The Passing of Traditional Society: Modernizing the Middle East. New York: The Free Press.

Mahmood, S. 2004. The Politics of Piety: The Islamic Revival and the Feminist Subject. Princeton, NJ: Princeton University Press.

$$
\text { . 2006. "Secularism, Hermeneutics, and Empire: The Politics of Islamic }
$$

Reformation." Public Culture 18, 323-347.

Masuzawa, T. 2005. The Invention of World Religions. Chicago: University of Chicago Press.

Mead, M. 1932. "An Investigation of the Thought of Primitive Children, with Special Reference to Animism," Journal of the Royal Anthropological Institute of Great Britain and Ireland 62, 173190.

Mitchell, T. 1988. Colonising Egypt. Cambridge: Cambridge University Press. . 2002. Rule of Experts: Egypt, Techno-Politics, Modernity. Berkeley: University of California Press.

Pascal, B. 1974 [1670] "The Wager." In B. Brody, ed., Readings in the Philosophy of Religion: An Analytical Approach. Englewood Cliffs, NJ: Prentice-Hall, pp. 227-229.

Pipes, D. 2002. “'Become a Muslim Warrior,'” Jerusalem Post, 3 July. Available at www.danielpipes.org. . 2004. "Spreading Islam in American Public Schools," FrontPageMagazine.Com, 24 November.

Rabasa, A., C. Benard, L. H. Schwartz, and P. Sickle. 2007. Building Moderate Muslim Networks. Rand Corporation.

Rappaport, R. 1983. "The Obvious Aspects of Ritual," in his Ecology, Meaning, and Religion (Berkeley, CA: North Atlantic Books), pp. 173-222.

Shimron, Y. 2007a. "E-mail thanks enemy of Islam: Teacher seems to bless evangelism." Raleigh News \& Observer 27 February. Available at www.newsobserver.com. 
. 2007b. "Enloe students questioned: Former students say teacher suspended this week often talked about Christianity." Raleigh News \& Observer 2 March. Available at www.newsobserver.com.

. 2007c. "Schools forbid selling religion: Teacher relocated after Enloe Episode." Raleigh News \& Observer 24 May. Available at www.newsobserver.com.

Smith, W. R. 1956 [1889]. The Religion of the Semites. New York: Meridian Books.

Soares, B. 2005. "Islam in Mali in the Neoliberal Era." African Affairs 105, 77-95.

Starrett, G. 2008. "When Theory is Data: Coming to Terms with 'Culture' as a Way of Life," in M. J. Brown, ed., Explaining Culture Scientifically. Seattle: University of Washington Press.

Sullivan, W. 1994. Paying the Words Extra: Religious Discourse in the Supreme Court of the United States. Cambridge, MA: Harvard University Press. . 2005. The Impossibility of Religious Freedom. Princeton, NJ: Princeton University Press.

Targoff, R. 1997. "The Performance of Prayer: Sincerity and Theatricality in Early Modern England." Representations 60, 49-69.

Taussig, M. 1993. Mimesis and Alterity: A Particular History of the Senses. New York: Routledge.

White, J. 2005. "Islamic Indoctrination in Scottsdale, Arizona Public School," reader comment on Pipes 2004, posted 27 February. Available at www.danielpipes.org. 


\section{NOTES}

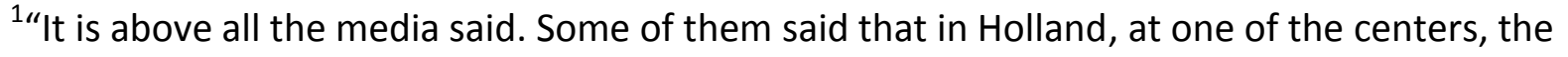
number of people who accepted Islam during the days that followed the [September 11] operations were more than the people who accepted Islam in the last eleven years." Osama bin Laden, from transcript at http://archives.cnn.com/2001/US/12/13/tape.transcript/

${ }^{2}$ Lemon $v$. Kurtzman concerned the constitutionality of providing state funds and services to students and employees of parochial schools; Lynch $v$. Donnelly centered on the issue of whether municipalities could display publicly funded religious symbols as part of holiday displays.

${ }^{3}$ Several times since that date, Muslims praying in public areas such as malls or airports in the U.S. have triggered reports to local or federal authorities of suspicious activity, the assumption being that would-be martyrs pray before conducting suicide attacks.

${ }^{4}$ See, for example, http://www.biblebelievers.org.au/moongod.htm, and http://www.chick.com/information/religions/islam/allah2.asp.

${ }^{5}$ The Ouija Board (implicated in the demonic possession in William Friedkin's 1973 film The Exorcist), is a divination game in which two players place their fingers on a flat marker which moves across a board printed with the letters of the alphabet. Participants ask the board questions, and the spelled-out answers are taken to be the work of spiritual forces. For more details, see Ellis 2000.

${ }^{6}$ Misconstrual may be a tactical decision, as when pundits at Pipes' website Campus Watch and related publications launched an effort in November 2006 to discredit University of Pennsylvania president Amy Gutmann by posting noisy denunciations of her actions at an annual Halloween party at her official residence. Like the parents of the trick-or-treater dressed as Osama bin Laden, Gutmann was criticized as unpatriotic and morally insensitive for having posed for photographs with a number of students dressed in costume, one of whom, an engineering student of Middle Eastern heritage, was dressed as a Muslim "martyr" complete with replica rifle and suicide belt (http://www.campus-watch.org/article/id/2941).
} 